\title{
Herbicide effects on vegetation spatial patterns in a mesquite savanna
}

\author{
CHANDRA B. HEATON, X. BEN WU, AND R. JAMES ANSLEY
}

Authors were Graduate Student, Associate Professor, Department of Rangeland Ecology and Management, Texas A\&M University, College Station, Tex. 77843; and Associate Professor, Texas Agricultural Experiment Station, Vernon, Tex. 76384. The corresponding author is Wu (b-wu@tamu.edu).

\begin{abstract}
Several studies have examined the impact of woody plant (i.e., brush) management efforts on mesquite (Prosopis glandulosa Torr.) cover and associated ecological impacts, but little research has been done on spatial attributes of vegetation following mesquite management treatments. This study examined the effects of above-ground mortality (triclopyr or 2,4,5-T) and whole-plant mortality (clopyralid or triclopyr+clopyralid) mesquite herbicide treatments on the canopy cover and spatial pattern of vegetation in a mesquite savanna and the associated ecological and management implications. A GIS and landscape analysis based on classified color-infrared aerial photos were used to quantify the spatial patterns of woody and non-woody vegetation. The results indicate long-term ( $>20$ year) persistence of disturbance effects on the amount and spatial pattern of woody vegetation. Significant differences in spatial pattern were found between the herbicide treatments and the non-treated plots, as well as between the above-ground mortality (AGM) and whole-plant mortality (WPM) herbicide treatments. The differential changes in the amount and spatial distribution of woody cover under different treatments resulted in substantially different spatial distributions of non-woody vegetation with respect to distance to nearest woody vegetation. These spatial variations may influence production and zonation of herbaceous vegetation due to modified shading and root competition from mesquite. Our results support observations of differential rates of mesquite seedling recruitment and establishment between treatment types. We conclude that consideration of spatial pattern should be an important component of future brush management plans.
\end{abstract}

Key Words: brush management, clopyralid, spatial pattern analysis, GIS and remote sensing, semi-arid rangeland

Shrub expansion into savanna and grassland systems over the past century has been documented throughout the world, including Texas and the southwestern United States (Grover and Musick 1990, Schlesinger et al. 1990, Archer et al. 1988, 1995, 2000, Ansley et al. 2001a). An important brush species in Texas and much of the southwestern United States is honey mesquite (Prosopis glandulosa Torr.). The increasing amounts of woody

This project was partially supported by the National Science Foundation through a Graduate Research Fellowship Award to Heaton, and by the Texas Agricultural Experiment Station. The W.T. Waggoner Estate, Vernon, Tex. provided the land area for the research. Authors wish to thank R.A. Masters, R. Feagin, and 2 anonymous reviewers for their constructive review comments that helped to improve the manuscript.

Manuscript accepted 24 Jan. 03.

\section{Resumen}

Varios estudios han examinado el impacto de los esfuerzos de manejo de las plantas leñosas (i.e. arbustos) en la cobertura de "Mesquite" (Prosopis glandulosa Torr.) y los impactos ecológicos asociados, pero poca investigación ha sido hecha sobre los atributos espaciales de la vegetación después de los tratamientos de manejo del "Mesquite". Este estudio examinó los efectos de la mortalidad aérea (triclopir or 2,4,5-T) y la mortalidad total de la planta (clopiralid o triclopir+clopiralid) en tratamientos de herbicidas para control de "Mesquite" en la cobertura de copa y patrón espacial de la vegetación en una savana de "Mesquite" y las implicaciones ecológicas y de manejo asociadas. Se uso un análisis de SIG y de paisaje basado en fotografías aéreas clasificadas de color-infrarrojo para cuantificar los patrones espaciales de la vegetación leñosa y no leñosa. Los resultados indican una persistencia a largo plazo ( $>20$ años) de los efectos de disturbio en la cantidad y patrón espacial de la vegetación leñosa. Se encontraron diferencias significativas en el patrón espacial entre los tratamientos de herbicidas y las parcelas no tratadas, así como entre los tratamientos de herbicida para mortalidad aérea (AGM) y mortalidad total de la planta (WPM). Los cambios diferenciales en la cantidad y distribución espacial de la cobertura leñosa bajo los diferentes tratamientos resultó en distribuciones espaciales substancialmente diferentes de la vegetación no leñosa con respecto a la distancia de la vegetación leñosa mas cercana. Estas variaciones espaciales pueden influir en la producción y zonificación de la vegetación herbácea debido al sombreado modificado y la competencia de raíz del "Mesquite". Nuestros resultados soportan las observaciones de tasas diferenciales de establecimiento de plántulas entre los tipos de tratamientos. Concluimos que la consideración del patrón espacial debe ser un componente importante de futuros planes de manejo de arbustos.

plants like mesquite have many ecological and management implications, including competition with herbaceous plants and associated reduction in forage availability (Dahl et al. 1978, Scifres et al. 1982, Bedunah and Sosebee 1984, Dye et al. 1995, Scholes and Archer 1997), changes in hydrology (Blackburn 1983, Wu et al. 2001), impacts on habitat of creatures ranging from soil microarthropods (Whitford and Sobhy 1999) to elf owls (Hardy et al. 1999) and feral hogs (Ilse and Hellgren 1995), plant species composition shifts (McPherson et al. 1988) and soil nutrient cycling (Knoop and Walker 1985, Connin et al. 1997, Gill and Burke 1999).

While many studies have examined the impact of mesquite control treatments on the abundance (i.e., cover and density) of 
mesquite (Brock et al. 1978, Scifres et al. 1982, Herbel et al. 1983, Bedunah and Sosebee 1984, Heitschmidt et al. 1986), little work has been done on the impact of these treatments on the subsequent spatial pattern of mesquite. An exception is Ansley et al.'s (2001a) study documenting the rate of change of mesquite cover as well as spatial variables (patch density, mean patch size, distance to nearest neighbor, mean shape index) over 20 years on a non-treated site as compared with a rootplowed site. Spatial variables may offer a more explicit description of an ecological system than consideration of percent cover (abundance) alone; the same amount of mesquite can be arranged in dramatically different ways, with impacts on ecological processes as well as management concerns. Spatial pattern may point to potential long-term landscape-level shifts in vegetation dynamics.

The use of various herbicides and herbicide combinations, and their effectiveness for control of honey mesquite and other woody species, have been extensively documented as summarized by Bovey (1998, 2001). Triclopyr (3,5,6-trichloro-2pyridinyloxyacetic acid, butyoxyethyl ester) and 2,4,5-T [(2,4,5-trichlorophenoxy) acetic acid] have been shown to successfully cause above-ground mortality (AGM), often resulting in basal resprouting of mesquite (Fisher et al. 1959, Dahl et al. 1978, Jacoby and Meadors 1983), while clopyralid (3,6-dichloro-2pyridinecarboxylic acid, monoethanolamine salt) has shown a greater ability to kill both the above-ground portions and roots of mesquite, resulting in whole-plant mortality (WPM) (Bovey and Whisenant 1991, 1992).

The objective of this study was to examine the long-term effects of AGM and WPM herbicide treatments on the spatial patterns of woody and non-woody vegetation in a mesquite savanna. Changes in spatial patterns of vegetation may have important ecological and management implications.

\section{Materials and Methods}

\section{Study Area}

The research site was located on the W.T. Waggoner Ranch, about $37 \mathrm{~km}$ southwest of Vernon, Tex. $\left(33^{\circ} 53^{\prime} \mathrm{N}\right.$., $99^{\circ} 21^{\prime}$ W.; elevation $380 \mathrm{~m}$ ), in the northern Rolling Plains ecoregion of Texas. The climate of the area is continental and semiarid. Mean annual precipitation is $65.2 \mathrm{~cm}$ at Vernon, with peak rainfall bimodally distributed in May and October. Mean annual air temperature is $17^{\circ} \mathrm{C}$. Soils are fine, mixed, thermic Typic Paleustolls of the Tillman and Wichita series, which are alluvial clay loams from 0 to 3-4 m depth, underlain by Permian sandstone/shale parent material (Koos et al. 1962). Vegetation on the site is dominated by a woody overstory of honey mesquite. Other woody species include lotebush (Ziziphus obtusifolia var. obtusifolia [Hook. Ex T.\&G.] Gray), tasajillo (Opuntia leptocaulis DC.), and plains pricklypear (Opuntia polycantha Haw.). The herbaceous species on the site are a mixture of cool-season (C3) and warm-season (C4) grasses. Primary coolseason grass species are the perennial midgrasses Texas wintergrass (Nassella leucotricha [Trin. and Rupr.] Barkworth.) and Texas bluegrass (Poa arachnifera Torr.), and the annual grass Japanese brome (Bromus japonicus Thunb ex. Murray). Warm season grasses are perennial short-grass buffalograss (Buchloe dactyloides [Nutt.] Engelm.), and midgrasses silver bluestem (Bothriochloa laguroides [DC.] Herter. Subsp. torreyana [Steud.]), meadow dropseed (Sporobolus compositus (Poir.) Merr. ), and sideoats grama (Bouteloua curtipendula [Michx.] Torr.). A moderate, continuous grazing regime has been in place for at least 50 years at a stocking rate of about $12 \mathrm{ha} / \mathrm{cow}$ (30 acre/cow).

\section{Herbicide Treatment and Experimental Plots}

The AGM (triclopyr or 2,4,5-T) or WPM (clopyralid or triclopyr + clopyralid) herbicides were aerially applied by a fixed-wing airplane to treatment areas within a set of pastures in 1977, 1979, 1987, and 1988 (Table 1) as a field test to evaluate the potential of various herbicides for mesquite control The treatments were applied in rectangular strips approximately $84 \mathrm{~m} \mathrm{x} 400 \mathrm{~m}$ (about $3.4 \mathrm{ha}$ ). Buffer strips (ca. $15 \mathrm{~m}$ ) were left between treatments. The non-treated areas had no record of any brush control for more than 30 years; ranch records indicate that the entire pasture was aerially sprayed with $2,4,5-\mathrm{T}$ in 1968. There was no internal fencing in the pasture, so cattle and wildlife were free to move across treatments. Canopy foliage, when averaged over all trees, was reduced equally by the AGM and WPM herbicide treatments (Table 1). The percentage of mesquite with AGM (all original stems killed and exhibiting basal re-growth) was slightly greater in the AGM than the WPM treatments in each spray year. Percent WPM (percent of mesquite with all original stems killed and exhibiting no regrowth) was substantially greater in the WPM than the AGM treatment, and greater in the WPM treatments applied in the 1970's than the 1980's.

The historical treatment setup and other alternations since then necessitated an unbalanced design for this study with unequal replications in each herbicide treatment and non-treated areas. Sixteen, 1-ha plots (each $71 \times 141 \mathrm{~m}$ ) were randomly located in each of 16 of the original 3.4 ha herbicide treatment strips. Of these 16 plots, 7 were in AGM treatments (4 in 12-year post-treatment and 3 in 22-year post-treatment areas), and 9 were in WPM treatments (5 in12-year post-treatment and 4 in 22-year post-treatment areas). Three other 1-ha plots were randomly located in untreated strips.

\section{Development of Vegetative Cover Maps}

Vegetative cover maps with woody and non-woody cover classes were developed from color infrared aerial photos taken on 2 September 2000 at a nominal scale of 1:5,000. The aerial photos were scanned into images with $0.5 \mathrm{~m}$ resolution and the images were geo-referenced using GPS coordinates taken in the field at points that were easily identifiable on the aerial photos.

To develop vegetative cover maps, the images were classified using the unsupervised classification procedure in ArcView

Table 1. Above-ground and whole-plant mortalities of herbicide treatments evaluated 2 years after herbicide application.

\begin{tabular}{lcccc}
\hline \hline $\begin{array}{l}\text { Herbicide } \\
\text { Treatment }\end{array}$ & $\begin{array}{c}\text { Year } \\
\text { Sprayed }\end{array}$ & $\begin{array}{c}\text { Canopy } \\
\text { Reduction }\end{array}$ & $\begin{array}{c}\text { Above Ground } \\
\text { Mortality }\end{array}$ & $\begin{array}{c}\text { Whole Plant } \\
\text { Mortality }\end{array}$ \\
\hline AGM $^{2}$ & -1977 or 1979 & $90(2)^{4}$ & $33(2)$ & $4(1)$ \\
AGM $^{3}$ & 1987 or 1988 & $87(4)$ & $45(19)$ & $2(1)$ \\
WPM $^{3}$ & 1977 or 1979 & $91(3)$ & $18(6)$ & $68(4)$ \\
WPM & 1987 or 1988 & $87(5)$ & $31(6)$ & $37(2)$ \\
\hline
\end{tabular}

${ }^{1}$ Plants with complete original stem mortality then basally re-sprouted.

${ }^{2} \mathrm{AGM}=$ above-ground mortality herbicide treatment using $0.56 \mathrm{~kg} \mathrm{ha}^{-1}$ triclopyr or $2,4,5-\mathrm{T}$

${ }^{3} \mathrm{WPM}=$ whole-plant mortality herbicide treatment using $0.56 \mathrm{~kg}^{-1}$ clopyralid or $0.28 \mathrm{~kg} \mathrm{ha}^{-1}$ clopyralid $+0.28 \mathrm{~kg} \mathrm{ha}^{-1}$ triclopyr.

${ }^{4}$ Standard error is shown in parentheses. 
Image Analysis. This classification method uses the Iterative Self-Organizing Data Analysis (ISODATA) technique to identify and group similar pixels based on the reflectance values of the pixels (ERDAS 1998). Forty (40) classes (groups of similar pixels) were generated with a convergence threshold of $95 \%$ (ERDAS 1998). These 40 classes were then manually assigned to either woody or non-woody categories using the original color infrared images as reference. Given that the overwhelming majority of the woody canopy cover consisted of mesquite (Ansley et al. 2001 b ), it was assumed that all woody vegetation on the images was mesquite.

Classification accuracy was assessed using visual interpretation of the aerial photos at 415 randomly selected points within the plots. The overall accuracy (Jensen 1996) of the classification (correct assignment of pixels into woody or nonwoody classes) of aerial photographs was $89.2 \%$. The producer's accuracy (measure of omission error) was $85 \%$ for woody and 92\% for non-woody, while user's accuracy (measure of commission error) was $89 \%$ for woody and $90 \%$ for non-woody. One likely source of error is that some of the smallest mesquite plants with sparse canopy were not detected in the classification process, although every effort was made to include as many as possible while maintaining the accuracy of the rest of the classification.

\section{Analysis of Patch-Based Spatial Pattern}

The spatial patterns of both woody and non-woody vegetation were quantified using 6 landscape variables: percent cover, mean patch size $\left(\mathrm{m}^{2}\right)$, patch density (number of patches $\mathrm{ha}^{-1}$ ), mean shape index, mean nearest neighbor distance $(\mathrm{m})$, and edge density (meters ha ${ }^{-1}$ ). Shape index is a measure of patch shape complexity defined as $0.25^{*} \mathrm{P} / \mathrm{A}^{1 / 2}$, where $\mathrm{P}$ is the perimeter and $\mathrm{A}$ is the area of the patch (McGarigal and Marks 1995). The shape index equals 1 for a square patch, the simplest raster shape, and increases when the shape of a patch becomes more complex. Nearest neighbor distance is the shortest edge-to-edge distance measured between a given patch and the nearest neighboring patch of the same type. Edge density is the total linear distance of all edges divided by the landscape area, expressed as meters of edge per hectare. It is important to note that a patch was defined as an area of continuous canopy, not an individual plant. One patch may encompass several mesquite trees if any parts of the canopies of these trees overlap in an aerial projection. Analyses of the spatial pattern of the vegetative cover map for each of the 19 plots were conducted using the ArcView Patch Analyst extension (Elkie et al. 1999) that was developed based on the landscape analysis software FRAGSTATS (McGarigal and Marks 1995).

Statistical tests of the effect of the herbicide treatments on the spatial pattern were conducted using the General Linear Model (GLM) procedure and specific contrasts in SAS (SAS 1994). A 1-way analysis of variance with 5 treatment levels (AGM-12 yr, AGM-22 yr, WPM-12 yr, WPM- 22 yr, and non-treated) was conducted using GLM for each of the 6 landscape variables for woody and non-woody patches, respectively. Five specific contrasts, AGM-12 yr vs. AGM-22 yr, WPM-12 yr vs. WPM-22 yr, AGM vs. non-treated, WPM vs. non-treated, and AGM vs. WPM, were conducted for each landscape variable of each vegetative cover type with significant overall treatment effects. A significance level of $\alpha=0.05$ was used for all statistical tests and was adjusted for the contrasts based on Bonferroni inequality (SAS 1994).

Frequency distribution of patch size and frequency distribution of distance to the nearest woody pixel from each non-woody pixel for each treatment type were also developed. This information was used to account for potential masking of interesting patterns due to the averaging of patches over the hectare plots.

\section{Lacunarity Analysis}

To obtain an integrative measure of change in underlying landscape pattern between treatment types, a lacunarity curve was developed for each of the 19 plots. Lacunarity is a metric of landscape texture and measures the deviation of a geometric structure from translational invariance, or the "gappiness" of a geometric structure (Plotnick et al. 1993). Lacunarity analysis has been used to quantify landscape patterns and their dynamics in rangeland studies (Wu et al. 2000, Derner and Wu 2001). Lacunarity was calculated using a procedure (Wu and Sui 2001) implemented in ArcView Spatial Analyst extension based on the "gliding box" algorithm (Allain and Cloitre 1991, Plotnick et al. 1993). To calculate lacunarity, the hectare vegetative cover maps were reclassified, assigning woody pixels a value of 1 and non-woody pixels a value of 0 . Lacunarity is calculated at multiple scales for a given landscape, in this case using gliding boxes with side length of
$0.5,1,2,4,8,16$, and $32 \mathrm{~m}$. A box of given side length $r$ was placed in 1 corner of the hectare map, and the sum of the values of all pixels contained within the box, called the "box mass" S(r), was calculated. The box was moved across the entire grid at 1-pixel intervals and the box mass determined at each location. Lacunarity (L) for box size $r$ was calculated as 1 plus the ratio of the variance and the mean square of the box mass for size $r$ : $L(r)=$ $\operatorname{var}[S(r)] / E[S(r)]^{2}+1$. A lacunarity curve, consisting of a log-log plot of lacunarity $L(r)$ against box size $r$, was generated for each plot to quantify the spatial pattern of the landscape at a range of scales. The range over which rapid decrease of lacunarity occurs, as indicated by the lacunarity curve, may indicate a domain of scale for a given landscape beyond which the spatial pattern becomes random. (Plotnick et al. 1993, Dale 2000).

The proportion of the landscape occupied by the habitat of interest (in this case, percent woody cover) influences lacunarity values, at least at small scales, because a higher percent cover will lead to higher mean box mass and therefore lower lacunarity values than a lower percent cover. To examine the pattern and scaling of spatial heterogeneity determined by spatial configuration independent of percent cover, lacunarity curves can be normalized to factor out the effect of percent cover (Plotnick et al. 1996). Normalized lacunarity curves were generated by rescaling the corresponding lacunarity curves, dividing the lacunarity value $L(r)$ at each box size $r$ by the value for box size $1(\ln [L(1)])$, so each curve would start at $r=1$ and $L(r)=$ 1 , and eventually approach 0 (Plotnick et al. 1996). Analysis of variance and specific contrasts using GLM procedure (SAS 1994), similar to those used above for patch-based landscape variables, were used to test the effect of herbicide treatments on lacunarity value and normalized $\ln$ (lacunarity), respectively, at each spatial scale (Derner and Wu 2001).

\section{Results and Discussion}

\section{Herbicide Effects}

Significant differences in landscape variables were found between the herbicide treatments and the non-treated areas, as well as between the above ground mortality (AGM) and whole plant mortality (WPM) herbicide treatments (Table 2), while there was no significant difference between 12- and 22-year post treatments of AGM or WPM for any of the landscape variables. Both AGM and WPM herbicide treatments significantly altered the long- 
term abundance and spatial pattern of woody and non-woody vegetation as compared with non-treated areas. Significant differences were also found between the 2 treatment types in percent cover, patch density and mean shape index (woody only).

For woody vegetation, WPM plots exhibited a high density of well-dispersed (large mean nearest neighbor distance) small patches with relatively simple shapes in comparison to AGM plots, which had a less dense arrangement of larger patches with more complex shapes, and non-treated plots with low densities of large, contiguous patches with relatively complex shapes (Table 2). The more complex patch shapes in the AGM than the WPM treatment are a reflection of basal regrowth from established root systems in the AGM treatment. The greater percent cover in the AGM than the WPM treatment is likely also due to a higher occurrence of basal re-growth in the AGM than in the WPM treatment. However, because not all mesquite were completely killed in the WPM treatment (Table 1), some mesquite in this treatment also had basal regrowth following treatment.

Mean woody patch size was greatest in the non-treated areas due to the presence of relatively old, large trees and coalescing/overlapping canopies of adjacent trees. The presence of large and complex woody patches formed by old multi-stemmed trees, often with overlapping canopies, is also indicated by the significantly higher mean shape index in the non-treated areas than in either herbicide treatment. In contrast, the relatively large non-woody mean patch size and mean shape index in the WPM treatment areas as compared to AGM and non-treated plots (Table 2) indicate a highly continuous and complex herbaceous matrix in the WPM treatment areas. The herbaceous component in the AGM areas is less continuous, while the herbaceous component in the non-treated areas is highly fragmented and consists of small, dispersed, non-woody patches in a highly continuous woody matrix. Ninetyeight percent $(98 \%)$ of the woody area in non-treated plots occurred in patches larger than $1,000 \mathrm{~m}^{2}$, while only $12 \%$ of the woody area in WPM plots occurs in this size class (Fig. 1a). In contrast, there were no non-woody patches larger than $1000 \mathrm{~m}^{2}$ in the non-treated plots while patches of this large size made up $98 \%$ of the nonwoody pixels in WPM plots and $74 \%$ of the non-woody pixels in AGM plots (Fig. 1b).

Edge density was considered as a potentially important variable due to findings by Brock et al. (1978) of differing herbaceous
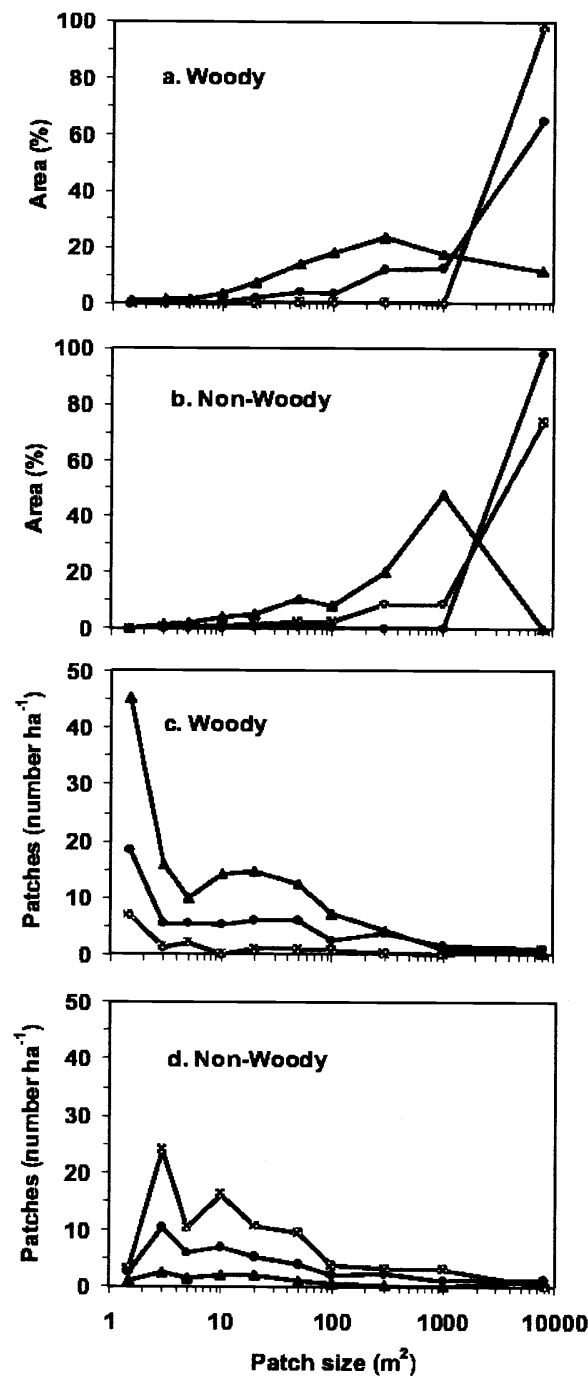

$\rightarrow$-Non-treated $\rightarrow-$ AGM $\rightarrow$ WPM

Fig. 1. Patch size distribution for woody (a,c) and non-woody (b,d) patches in the above-ground mortality (AGM) and whole-plant mortality (WPM) herbicide treatment (12- and 22-year post treatment combined) areas as compared with the non-treated areas. Size classes used were: 0-1.4. 1.5-2.9, 3.0-4.9, 5.0-9.9, 10-19.9, 20-49.9, 50-99.9, 100-299.9, 300-999.9, $1,000-2,999.9$, and $3,000-10,000 \mathrm{~m}^{2}$. Panels (a) and (b) illustrate the percentage of woody or non-woody area accounted for by each patch size class; panels (c) and (d) illustrate number of patches within each size class per hectare.

species composition in 3 zones surrounding mesquite plants. A higher amount of edge may lead to more abundant transition zone vegetation. Despite the large differences in the percent cover and other spatial variables, edge density of mesquite was not significantly different between treatment types. This is likely due to the large number of small woody patches in the treated areas with lower percent woody cover, relative to the few large woody patches in non-treated areas with high percent woody cover (Table 2 ).

Simultaneous consideration of multiple landscape variables of percent cover, mean patch size, patch density, mean shape index, as well as the frequency distributions of patch size and distance to woody pixels, captures different aspects of spatial pattern and paints a more ecologically meaningful picture than consideration of any one of these variables singularly. Since lacunarity reflects both the attributes of the patches and their spatial arrangement in landscapes, lacunarity curves can integrate the information captured in these multiple landscape variables and provide a concise and multiple-scale representation of the differing landscape patterns of the various treatments. The WPM plots had the highest lacunarity values, followed by AGM plots, and nontreated plots had the lowest lacunarity values (Fig. 2a). The significantly higher lacunarity values in WPM than AGM and non-treated areas at all but the largest scales indicate a wide range of non-woody gap sizes and a high level of spatial heterogeneity or aggregation of the landscape
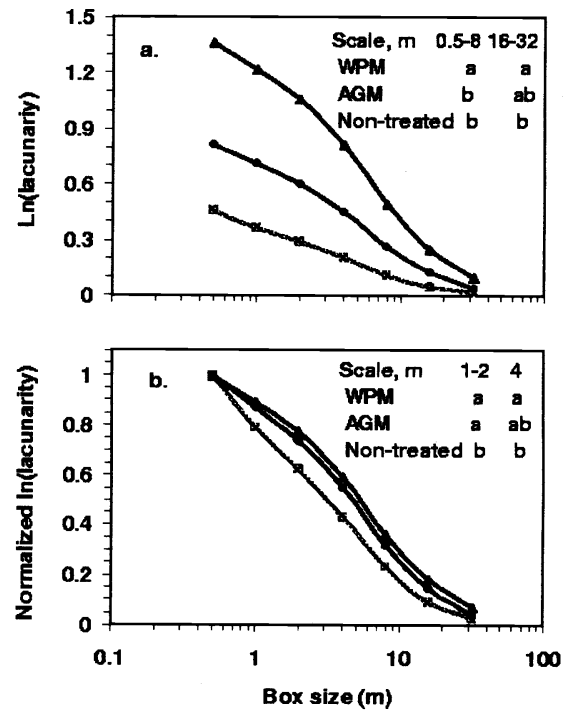

- Non-treated $\rightarrow$ AGM $\leftarrow$ WPM

Fig. 2. Lacunarity curves (a) and normalized lacunarity curves (b) for above-ground mortality (AGM) and whole-plant mortality (WPM) herbicide treatments (12- and 22-year post treatment combined) and the non-treated areas. Significant $(\alpha=\mathbf{0 . 0 5})$ differences between curves are denoted by different letters at specific dates. 
Table 2. Mean values of landscape variables for woody and non-woody components of the aboveground mortality (AGM) and whole-plant mortality (WPM) herbicide treatment ${ }^{1}$ areas and the non-treated areas.

\begin{tabular}{lcccccc}
\hline \hline & & Woody & \multicolumn{3}{c}{ Non-woody } \\
& Non-treated & AGM & WPM & Non-treated & AGM & WPM \\
\hline Cover (\%) & $71^{\mathrm{a} 2}$ & $49^{\mathrm{b}}$ & $28^{\mathrm{c}}$ & $28^{\mathrm{a}}$ & $50^{\mathrm{b}}$ & $71^{\mathrm{c}}$ \\
Patch density (number ha-1) & $14^{\mathrm{a}}$ & $56^{\mathrm{a}}$ & $125^{\mathrm{b}}$ & $84^{\mathrm{a}}$ & $41^{\mathrm{b}}$ & $12^{\mathrm{c}}$ \\
Mean patch size (m2) & $549^{\mathrm{a}}$ & $128^{\mathrm{b}}$ & $25^{\mathrm{b}}$ & 34 & 221 & 1074 \\
Mean shape index & $1.70^{\mathrm{a}}$ & $1.50^{\mathrm{a}}$ & 1.36 & 1.33 & 1.58 & 2.20 \\
Mean nearest neighbor dist. (m) & 1.38 & 1.66 & 1.84 & 2.03 & 1.29 & 1.32 \\
Edge density (m ha-1) & 2689 & 2958 & 2804 & 2467 & 2943 & 2935 \\
\hline
\end{tabular}

Data in AGM and WPM columns include both 12- and 22-year post treatment plots. There was no significant difference between 12- and 22-year post treatment groups of AGM or WPM for any of the landscape variables.

${ }^{2}$ For landscape variables with significant treatment effect, significant differences $(\alpha<0.05)$ between treatment types within woody or non-woody component are indicated by different superscript letters. types. This reflects the pattern of fragmented woody cover with many small patches (single- or few-stemmed recruits) and some larger patches where plants that survived the WPM treatment exhibit multi-stemmed regrowth. The non-treated areas had the lowest lacunarity values because of higher cover and more even spatial distribution of the woody vegetation. When lacunarity curves were normalized to factor out the effect of percent cover, the difference between normalized lacunarity curves for WPM and AGM became insignificant; however, both curves were significantly greater than that for non-treated plots at intermediate scales and had larger domains of scale than that of the non-treated plots (Fig. 2b). Normalized lacunarity curves demonstrate persistence of the underlying difference in the pattern and scaling of the landscape configuration between the treated and nontreated areas, and similarity between the WPM and AGM areas, regardless of percent woody cover.

\section{Seedling Recruitment and \\ Establishment}

Treatment of WPM or AGM may lead to differential seedling recruitment and establishment rates. Field observations indicated that many more small, single-stemmed trees were growing in WPM areas than in AGM areas dominated by multi-stemmed plants, presumably from resprouting subsequent to mortality of above-ground material. This general observation, which has not been quantified in published studies of which we are aware, is supported by the results of the spatial analyses in this study, namely the smaller mean woody patch size, more dispersed distribution, higher woody patch density and lower mean shape index in WPM as compared to AGM plots (Table 2).

The mean patch size was significantly in WPM relative to the other 2 treatment in non-treated plots $\left(549 \mathrm{~m}^{2}\right)$, and also showed a trend (although non-significant) toward smaller size than AGM treatments $\left(128 \mathrm{~m}^{2}\right)$. Not only were the mean patch sizes different, there were also considerable differences in patch size distribution among non-treated, AGM, and WPM plots (Fig. 1). For the smallest size class (area $1.5 \mathrm{~m}^{2}$ or smaller), WPM plots averaged 45 woody patches $\mathrm{ha}^{-1}$, compared to 18 woody patches $\mathrm{ha}^{-1}$ in AGM plots and 7 woody patches $\mathrm{ha}^{-1}$ in non-treated plots (Fig. 1c). Very few non-woody patches of area $1.5 \mathrm{~m}^{2}$ or smaller were found in any of the 3 plot types; however, in the next size class $(1.5 \mathrm{~m} \leq$ area $\leq 3 \mathrm{~m})$ there are 10 times more non-woody patches per hectare in the non-treated than in the WPM plots (24 vs. 2.5) (Fig. 1d).

The smaller mean patch size and larger mean nearest neighbor distance of the WPM areas (Table 2) and frequency distribution of distance from each non-woody pixel to the nearest woody pixel (Fig. 3) indicate not only smaller but also more smaller in WPM treatments $\left(25 \mathrm{~m}^{2}\right)$ than dispersed mesquite in these areas. The frequency of distance from each non-woody pixel to the nearest woody pixel was most evenly distributed among various distances in WPM plots, while AGM and non-treated plots had a majority of pixels within $0.5 \mathrm{~m}$ of a woody pixel; $81 \%$ of the pixels in the non-treated plots and $61 \%$ of the pixels in AGM plots were within 0.5 meter of a woody pixel, while only $39 \%$ of the pixels in WPM plots were located this close to the nearest woody pixel (Fig. 3). At every measured distance from nearest woody pixel greater than $0.5 \mathrm{~m}$, WPM plots had a higher percentage of pixels than both AGM and non-treated plots.

Mean nearest neighbor distance in the woody component also indicated a more dispersed pattern of woody vegetation, the mean distance between neighboring woody patches increasing from non-treated to AGM to WPM plots, although no significant treatment effect was found (Table 2); in the non-woody component, there was a trend toward longer nearest neighbor distances in non-treated plots than in either AGM or WPM plots (Table 2).

Woody patch density was significantly higher in WPM plots $\left(125 \mathrm{ha}^{-1}\right)$ than in AGM $\left(56 \mathrm{ha}^{-1}\right)$ or non-treated plots $\left(14 \mathrm{ha}^{-1}\right)$ (Table 2). High density of smaller patches possibly reflects the presence of many isolated mesquite recruits from seed whose canopies do not overlap with those of adjacent mesquite. The low woody mean shape index values for the WPM plots indicated the simplest mesquite canopy shapes among the three treatment types. This would be expected for plots characterized by a high proportion of single- to few-stemmed plants emerged from seed rather than multi-stemmed growth forms

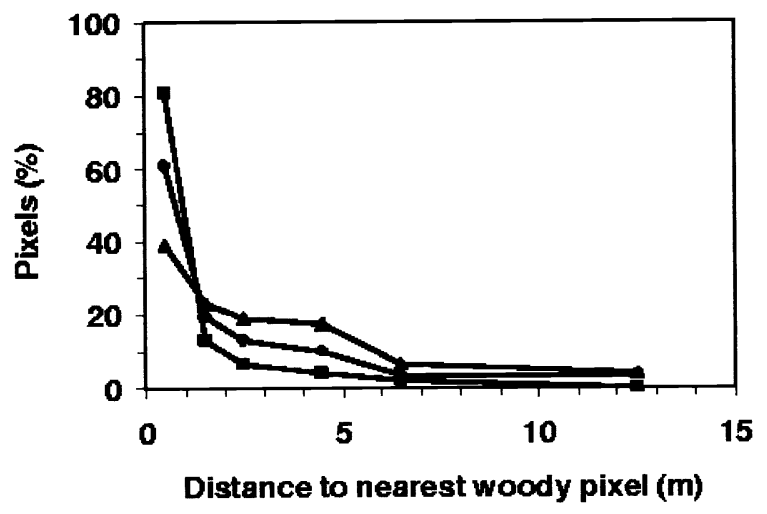

-Non-treated - AGM - WPM

Fig. 3. Frequency distribution of distance from every non-woody pixel to the nearest woody pixel, for above-ground mortality (AGM) and whole-plant mortality (WPM) herbicide treatments (12- and 22-year post treatment combined) and the non-treated areas. 
with more complex shapes resulting from resprouting after AGM herbicide treatment.

Changes in recruitment and establishment of mesquite following herbicide treatments might be due to reduction of competition from lateral roots following high rates of whole-plant mortality in WPM treatment areas. Studies have demonstrated the large areal extent of mesquite lateral roots (Heitschmidt et al. 1988, Scholes and Archer 1997) as well as the importance of these roots to the overall water use by mesquite (Ansley et al. 1990, 1998). The competition of mesquite for water resources is not limited to the area immediately surrounding each mesquite tree, but occurs in the interstitial areas between trees as well (Ansley et al. 1990, 1998, Scholes and Archer 1997). Reduction of this competition following WPM treatments may lead to increased opportunity for recruitment and establishment of new seedlings, as opposed to nonsprayed areas where little whole-plant mortality occurs, or AGM treatments where re-growth from stem bases rapidly restores competitive influence.

The process of recruitment of mesquite seeds is facilitated largely by livestock (cattle) dissemination of mesquite seeds via fecal deposition, although many wildlife species from deer to coyote may also contribute to this process (Brown and Archer 1987, Kramp et al. 1998). Seeds may be transported several hundreds of meters, if not kilometers, from the source plant through this process. Mesquite seeds must be scarified prior to germination, and passage through animal digestive systems provides this scarification. Seeds deposited in fecal matter are also advantaged by the ready nutrient-rich growth medium. It is likely that the experimental design may have encouraged dispersal of seed into the more open WPM areas. There are no fences between the various treatments, and animals (both domestic cattle and wildlife) roam freely throughout the site, with access to non-treated areas that provide shade and are an abundant source of mesquite seeds. Herbaceous production tends to be highest in open WPM areas (Dahl et al. 1978, Bedunah and Sosebee 1984, Ansley et al. 2001b), therefore animals (cattle and wildlife) may potentially spend more time grazing in these areas, and defecating mesquite seeds that they may have ingested.

\section{Management Implications}

The higher percent woody cover in the above ground mortality (AGM) versus the whole plant mortality (WPM) areas, likely due to the basal sprouting of mesquite plants following application of AGM herbicides, may have considerable impact on forage production (Dahl et al. 1978, Herbel et al. 1983, Laxson et al. 1997), and is therefore of interest for management considerations of livestock production and wildlife. In addition to differences in percent cover, the spatial pattern of mesquite following treatment, which can influence the level of competition between mesquite and herbaceous species, has direct implications for production in the herbaceous layer. Spatial patterns of mesquite, such as patch density, size, and arrangement may influence animal movement and foraging behavior (Etzenhouser et al. 1998) and the level of difficulty in herding livestock.

The significant differences found between non-treated areas and areas of up to 22 years post-treatment indicate considerable longevity of the herbicide treatments. This agrees with estimates of treatment longevity of at least 20 years used in studies of the economics of brush control in this region of Texas (Whitson and Scifres 1981). Differing spatial attributes were most pronounced between the nontreated and the WPM plots, indicating a greater impact of WPM than AGM herbicides on woody vegetation amount and spatial pattern. These results are supported by a recent study of the economics of mesquite control with herbicide application in the Rolling Plains region of Texas, in which WPM treatments were found to be economically viable and AGM treatments were not, despite the higher treatment cost of WPM (ca. \$59/ha) vs. AGM (ca. $\$ 37 / \mathrm{ha}$ ) application (Teague et al. 2001).

Differing patterns of woody vegetation resulting from treatment may lead to different properties of mesquite savannas in the future, depending on subsequent management decisions. A high density of small patches may lead to more abundant dense stands of mesquite in WPM areas as trees grow larger, or a more open understory may result from growth of singlestemmed seedlings as opposed to multistemmed regrowth from existing crowns. The implications for future characteristics of a mesquite savanna will change depending on follow-up treatments subsequent to initial herbicide spraying.

\section{Conclusions}

Significant differences were found in percent cover and spatial pattern of woody and non-woody vegetation in a honey mesquite savanna in northern Texas, between non-treated plots and the herbicide treatments for mesquite control, as well as between the 2 different treatments, one yielded high above ground mortality and low whole plant mortality (AGM treatment) and the other yielded high whole plant mortality (WPM treatment). Differing spatial pattern was illustrated by simultaneous consideration of multiple landscape metrics.

Lacunarity analysis was effective for quantifying and differentiating the spatial patterns of different treatments at multiple scales. Normalized lacunarity curves, which factored out the influence of varying amounts of woody cover between treatment types and the non-sprayed areas, demonstrated that the brush control treatments considered had an impact on the underlying spatial pattern of vegetation, regardless of percent cover. This changed spatial pattern may influence long-term ecology and management of brush control treatments.

Results from spatial analysis support observations of a higher level of seedling recruitment in the WPM plots than in either the AGM or non-treated plots. These differential recruitment rates may be a function of reduced competition from mesquite lateral roots in the WPM plots and possibly increased seed dispersal into the WPM plots via fecal deposition by cattle moving freely among the treated and non-treated areas.

Spatial patterns of vegetation have not been widely considered in the mesquite management literature, which has focused on the response of herbaceous vegetation to mesquite removal. Differing spatial patterns and patch attributes following mesquite herbicide treatments may have important impacts on current ecological processes as well as the future characteristics of mesquite savannas. Spatial patterns of mesquite resulting from different treatments should be an important consideration in the design and decision-making of long-term mesquite management practices.

\section{Literature Cited}

Allain, C. and M. Cloitre. 1991. Characterizing the lacunarity of random and deterministic fractal sets. Physical Rev. A 44:3552-3558.

Ansley, R.J., P.W. Jacoby, and G.J. Coumo. 1990. Water relations of honey mesquite following severing of lateral roots: influence of location and amount of subsurface water. $\mathrm{J}$. Range Manage. 43:436-442.

Ansley, R.J., B.A. Trevino, and P.W. Jacoby. 1998. Intraspecific competition in honey mesquite: Leaf and whole plant responses. J. Range Manage. 51:345-352. 
Ansley, R.J., X.B. Wu, and B.A. Kramp. 2001a. Observation: Long-term increases in mesquite canopy cover in a north Texas savanna. J. Range Manage. 54:171-176.

Ansley, R.J., B.A. Kramp, J. Nelson and J. Wallace. 2001b. Long-term forage responses to mesquite herbicide treatments. Abstr. In: Proc. Soc. Range Manage., $54^{\text {th }}$ Annual Meeting, Kailua-Kona, Hawaii (p 11).

Archer, S., T.W. Boutton, and K.A. Hibbard. 2000. Trees in grasslands: biogeochemical consequences of woody plant expansion. p. 115-137, in E.D. Schulze, S. Harrison, M. Heimann, E. Holland, J. Lloyd, I. Prentice and D. Schimel (Eds.) Global biogeochemical cycles in the climate system. Academic Press, San Diego, Calif.

Archer, S., D.S. Schimel, and E.A. Holland. 1995. Mechanisms of shrubland expansion: Land use, climate or $\mathrm{CO}_{2}$ ? Climatic Change 29:91-99.

Archer, S., C. Scifres, C.R. Bassham, and R. Maggio. 1988. Autogenic succession in a subtropical savanna: conversion of grassland to thorn woodland. Ecol. Monogr. 58:111-127.

Bedunah, D.J. and R.E. Sosebee. 1984. Forage response of a mesquite-buffalograss community following range rehabilitation. J. Range Manage. 37:483-487.

Blackburn, W.H. 1983. Influence of brush control on hydrologic characteristics of range watersheds. In: McDaniels, K. (Ed.) Proceedings, Brush Management Symposium Texas Tech. Univ. Lubbock, Tex.

Bovey, R.W. 1998. Herbicide absorption and transport in honey mesquite and associated woody plants in Texas. Texas Agr. Exp. Sta. Bull. 1728, Texas A\&M Univ., College Station, Tex.

Bovey, R.W. 2001. Woody plants and woody plant management: Ecology, safety, and environmental impact. Marcel Dekker, N.Y.

Bovey, R.W. and S.G. Whisenant. 1991. Control of honey mesquite with clopyralid, triclopyr, or clopyralid:triclopyr mixtures. J. Range Manage. 44:52-55.

Bovey, R. W. and S.G. Whisenant. 1992. Honey mesquite (Prosopis glandulosa) control by synergistic action of clopyralid:triclopyr mixtures. Weed Sci. 40:563-567.

Brock, J.H., R.H. Haas, and J.C. Shaver. 1978. Zonation of herbaceous vegetation associated with honey mesquite in northcentral Texas. Proceedings of the First International Range Conference, Soc. for Range Manage., Denver, Colo. (p 187-189).

Brown, J.R. and S. Archer. 1987. Woody plant seed dispersal and gap formation in a North American subtropical savanna woodland: The role of domestic herbivores. Vegetatio 73:73-80.

Connin, S.L., R.A. Virginia, and C.P Chamberlain. 1997. Carbon isotopes reveal soil organic matter dynamics following arid land shrub expansion. Oecologia 110:374-386.

Dahl, B.E., R.E. Sosebee, J.P. Goen, and C.S. Brumley. 1978. Will mesquite control with 2,4,5-T enhance grass production? J. Range Manage. 31:129-131.
Dale, M.R.T. 2000. Lacunarity analysis of spatial pattern: A comparison. Landscape Ecol. 15(5):467-478.

Derner, J.D. and X.B. Wu. 2001. Light distribution in mesic grasslands: Spatial patterns and temporal dynamics. Appl. Veg. Sci. 4:189-196.

Dye, K.L., D.N. Ueckert, and S.G. Whisenant. 1995. Redberry juniper-herbaceous understory interactions. J. Range Manage. 48:100-107.

Elkie, P.C., R.S. Rempel, and A.P. Carr. 1999. Patch Analyst User's Manual. Ont. Min. Natur. Resour. Northwest Sci. \& Technol. Thunder Bay, Ont. TM-002. 16pp + Append.

ERDAS. 1998. Using ArcView Image Analysis. ERDAS Inc. Atlanta, Ga.

Etzenhouser, M.J., M.K. Owens, D.E. Spalinger, and S.B. Murden. 1998. Foraging behavior of browsing ruminants in a heterogeneous landscape. Landscape Ecol. 13:55-64.

Fisher, C.E., C.H. Meadors, R. Behrens, E.D. Robinson, P.T. Marion, and H.L. Morton. 1959. Control of mesquite on grazing lands. Texas Agr. Exp. Sta. Bull. 935, Texas A\&M Univ., College Station, Tex.

Gill, R.A. and I.C. Burke. 1999. Ecosystem consequences of plant lifeform changes at three sites in the semiarid U.S. Oecologia 121:551-563.

Grover, H.D. and H.B. Musick. 1990 Shrubland encroachment in southern New Mexico, USA: and analysis of desertification processes in the American southwest. Climatic Change 17:305-330.

Hardy, P.C., M.L. Morrison, and R. X. Barry. 1999. Abundance and habitat associations of elf owls and western screech-owls in the Sonoran Desert. Southwest. Nat. 44:311-323.

Heitschmidt, R.K., R.D. Schultz, and C.J. Scifres. 1986. Herbaceous biomass dynamics and net primary production following chemical control of honey mesquite. J. Range Manage. 39:67-71.

Heitschmidt, R.K., R.J. Ansley, S.L. Dowhower, P.W. Jacoby, and D.L. Price. 1988. Some observations from the excavation of honey mesquite root systems. J. Range Manage. 41:227-231.

Herbel, C.H., W.L. Gould, W.F. Leifeste and R.P. Gibbens. 1983. Herbicide treatment and vegetation response to treatment of mesquites in southern New Mexico. J. Range Manage. 36:149-151.

Ilse, L.M., and E.C. Hellgren. 1995. Resource portioning in sympatric populations of collared peccaries and feral hogs in southern Texas. J. Mammal. 76:784-799.

Jacoby, P.W. and C.H. Meadors. 1983. Triclopyr for control of honey mesquite. Weed Sci. 31:681-685.

Jensen, J.R. 1996. Introductory digital image processing: A remote sensing perspective. Prentice Hall, Inc., N.J.

Knoop, W.T. and B.H. Walker. 1985 Interaction of woody and herbaceous vegetation in a southern African savanna. J. Ecol. 73:235--253.

Koos, W.M., J.C. Williams, and M.L. Dixion. 1962. Soil survey of Wilbarger County, Texas. USDA-SCS, Soil Survey Series 1959, Number 18, Fort Worth, Tex.
Kramp, B.A., R.J. Ansley and T.R. Tunnell. 1998. Survival of mesquite seedlings emerging from cattle and wildlife feces in a semiarid grassland. Southwest. Nat. 43(3):300-312.

Laxson, J.D., W.H. Schacht, and M.K. Owens. 1997. Above-ground biomass yields at different densities of honey mesquite. J. Range Manage. 50:550-554.

McGarigal, K. and B.J. Marks. 1995. FRAGSTATS: Spatial pattern analysis program for quantifying landscape structure. USDA For. Serv. Pacific Northwest Res. Sta. Gen. Tech. Rep. 351.

McPherson, G.R., H.A. Wright, and D.B. Webster. 1988. Patterns of shrub invasion in semiarid Texas grasslands. Am. Midl. Nat. 120:391-397.

Plotnick, R.E., R.H. Gardner, and R.V. O'Neill. 1993. Lacunarity indices as measures of landscape texture. Landscape Ecol. 8:201-211.

Plotnick, R.E., R.H. Gardner, W.W. Hargrove, $K$. Prestegaard, and $M$. Perlmutter. 1996. Lacunarity analysis: a general technique for the analysis of spatial patterns. Physical Rev. E 53:5461-5468.

SAS Institute Inc. 1994. SAS/STAT User's Guide, Release $6.034^{\text {th }}$ Edition. SAS Institute, Inc., Cary, N.C.

Schlesinger, W.H., J. F. Reynolds, G. L. Cunningham, L.F. Huenneke, W.M. Jarrell, R.A. Virginia, and W.G. Whitford. 1990. Biological feedbacks in global desertification. Sci. 247:1043-1048.

Scholes, R.J. and S. Archer. 1997. Tree-grass interactions in savannas. Annu. Rev. Ecol. Syst. 28:517-544.

Scifres, C.J., J.L. Mutz, R.E. Whitson, and D.L. Drawe. 1982. Interrelationships of huisache canopy cover with range forage on the Coastal Prairie. J. Range Manage. 35:558-562.

Teague, W.R., R.J. Ansley, U.P. Kreuter, J.M. McGrann and W.E. Pinchak. 2001. Economics of managing mesquite with prescribed fire or root-killing herbicides: a sensitivity analysis. J. Range Manage. 54:553-560.

Whitford, W.G. and H.M. Sobhy. 1999. Effects of repeated drought on soil microarthropod communities in the northern Chihuahuan Desert. Biol. Fertil. Soils 28:117-120.

Whitson, R.E. and C.J. Scifres. 1981 Economic comparison of honey mesquite control methods with special reference to the Texas Rolling Plains. J. Range Manage. $34: 415-420$

Wu, X.B. and D.Z. Sui. 2001. An initial exploration of a lacunarity-based segregation measure. Environ. Plann. B 28:433-446.

Wu, X.B., E.J. Redeker, and T.L. Thurow. 2001. Vegetation and water yield dynamics in an Edwards Plateau watershed. J. Range Manage. 54:98-105.

Wu, X.B., T.L. Thurow, and S.G. Whisenant. 2000. Fragmentation and changes in hydrologic function of tiger bush landscapes, southwest Niger. J. Ecol. 88(5):790-800. 